\title{
The Impact of Home-Based Business Processing Palm Sugar to Increase Socio-Economic Welfare of Farmers In South Halmahera Regency
}

\author{
${ }^{1}$ Alwia Usman, ${ }^{2}$ Agus Suman, ${ }^{3}$ Luchman Hakim, ${ }^{4}$ Wahib Muhaimin \\ ${ }^{12,}$ Faculty of Economic and Business Brawijaya University \\ ${ }^{3}$ Faculty of Biology Brawijaya University \\ ${ }^{4}$ Faculty of Social and Economic agriculture Brawijaya University
}

\begin{abstract}
This study was to observe the activities of home-based businesses (Home Industry) farmers palm tapper and its impact on the socio-economic welfare of farm families. Socio-economic welfare of farm families is measured with indicators of the fulfillment of needs for food, clothing, shelter, education, health, and social life as well as to describe the process of making juice until molded into palm sugar. his research was conducted in three villages namely Papaloang, Village and Countryside Village Makian, Hidayat South Halmahera. Samples were taken of 100 people by random sampling. Data was collected through interviews and observations. The data were analyzed qualitatively and quantitatively. The results showed that activities tapper palm farmers in South Halmahera district can, contributing to increase the socio-economic welfare of farmers tapping palm.
\end{abstract}

Keywords: Impact, Palm Sugar, Social Economy, Farmers

\section{Introduction}

Cottage industry processing palm sugar is a form of small business that can increase income and welfare in rural. Palm sugar is processed from the sap, sap contained in some plants of the Arecaceae tribe, one of which contained the palm trees (Arenga pinnata) [1]. Water produced by the sap of palm trees in addition can be used as raw material for making traditional drinks (legen), traditional liquor (wine), vinegar and palm sugar. Palm sugar is a product that has the potential to generate substantial revenue. This is because there is a flavor and aroma, and color typical of the palm sugar.

Sugar has been known by the people of Indonesia as one of the food and beverage sweetener [2]. Palm sugar obtained from palm juice tapping process which then reduced the water content to be solid. Product palm sugar is in the form of sugar that is printed with a coconut shell [3]. Opportunities utilization of palm trees, especially for the manufacture of palm sugar is still very open and not breathing decreased and during this time the need for palm sugar always has increased, especially in moments before Eid or Christmas [4].

Palm sugar derived from palm tree sap is preferred by consumers compared to other sugar products. Therefore, palm sugar industry is an alternative to improve the welfare of the community, because the processing is still done traditionally with very minimal capital. Opportunities utilization of palm trees, especially for the manufacture of palm sugar is still wide open. The demand for commodities is not breathing and during this decline are still unmet needs. Palm sugar derived from palm tree sap is preferred by consumers compared to other sugar products. By him, palm sugar home industry is an alternative to improve the welfare of farmers tapping sap, because processing can be done simply and with minimal capital.

The study was conducted over six months, starting from June 2013 to November 2013 is very important to know the extent of the impact of home-based businesses palm sugar industry for improving the welfare of farmers as well as tapping palm palm sugar maker The South Halmahera.

The problem in this study is tapping sap and palm sugar manufacture has been carried out, even in the hundreds of years but there is no detailed description of the increasing social and economic welfare efforts palm juice tapping tapper to family farmers. The purpose of this study is To find out the impact of business processing Palm sugar for enhancement of socio-economic well-being of farmers in South Halmahera

\subsection{Location and Time}

\section{Method Research}

The study was conducted over six months, starting from June until December 2013, the location of the research carried out in three villages namely Papaloang, Makean Village, and Village Tomori in southern Halmahera (Figure 1). 


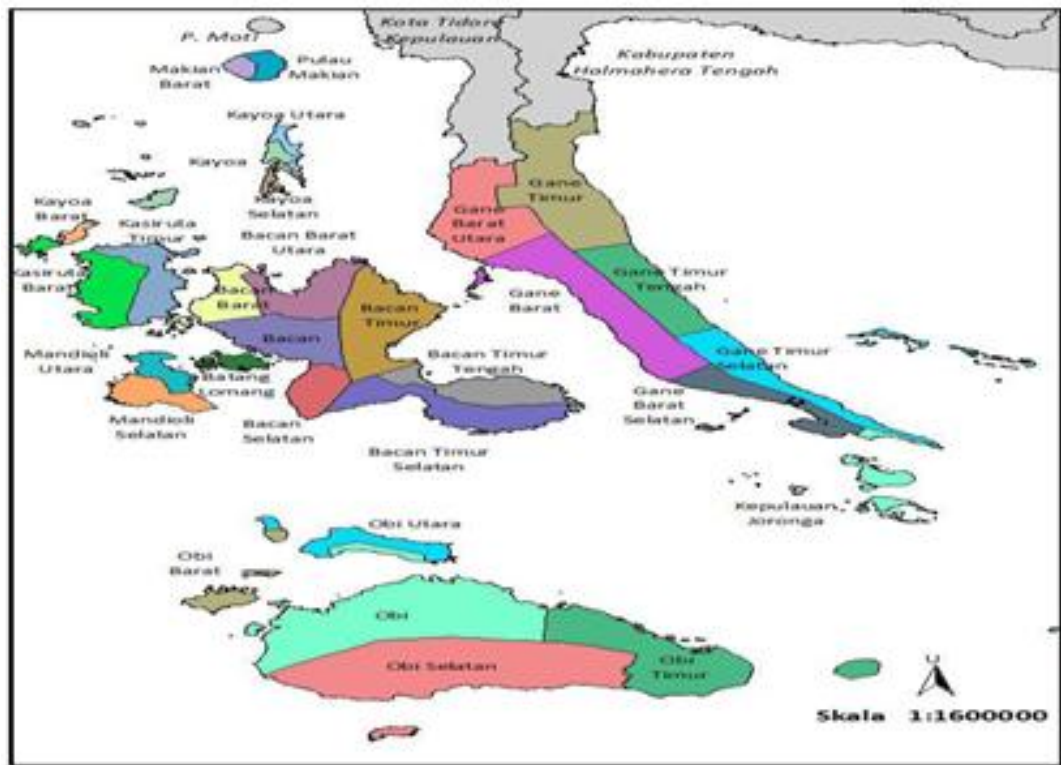

Figure 1. Research Location Map of South Halmahera

Source: The Regional Development Planning Board South Halmahera Regency

\subsection{Stages of Implementation Research}

Stages of research, the researcher cites the opinion qualitative research phase can be described in the following scheme [5]:

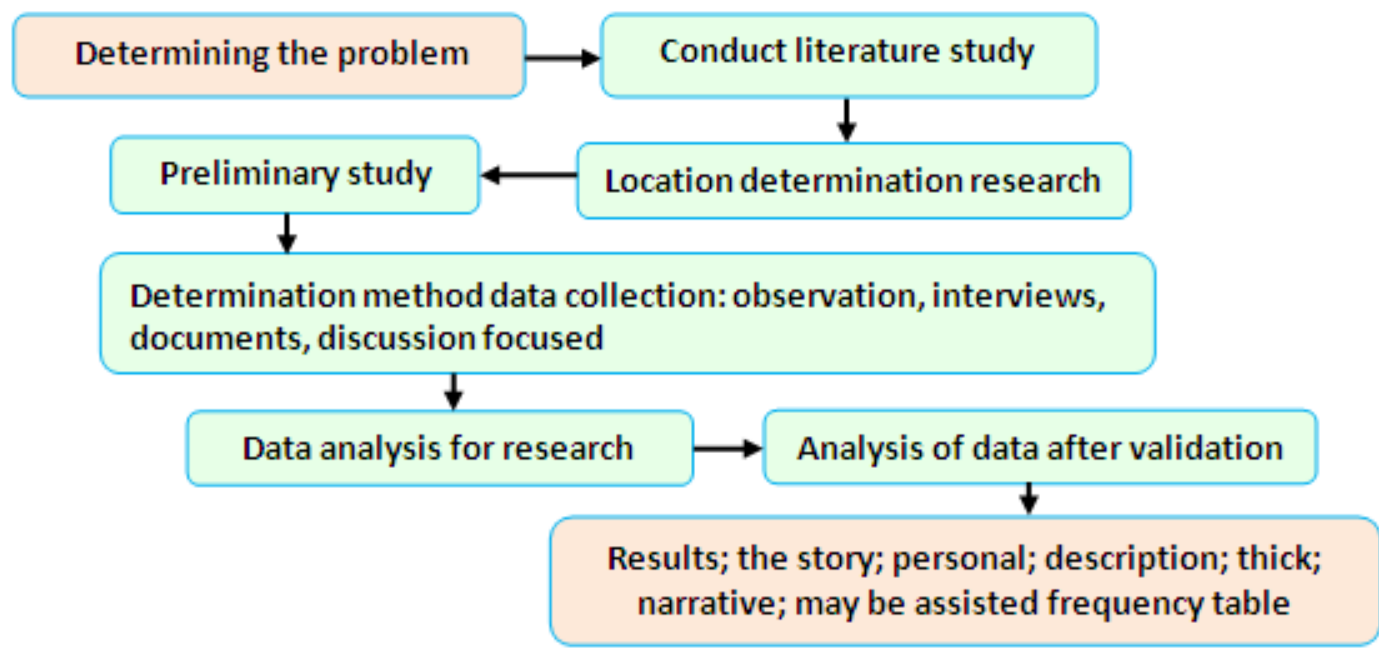

Figure 2. Stages of Qualitative Research

\subsection{Farmer Profile Aren}

\section{Results And Discussion}

Based on data from informants from three villages in South Halmahera District, the village Papaloang, Makian Kampong village, and village informants Tomori taken as many as 100 people with a population of 390 farmers, can be described as follows: Venture capital to make the sap into sugar arenpun not too large so that farmers do not need to tapper borrow money from banks or other business entities as initial capital.

Raw materials used only for tapping the sap of palm trees. Labor is used only on the scope of the immediate family like wife and children, so as to optimally utilize time as working at home or in garden where they grow sugar, so that family members are busy working and can avoid the negative association, such as drunkenness, gambling, behavior leading to social problems in the community, such as fights and poverty. So by giving jobs to family members means that can help social issues in the community. 


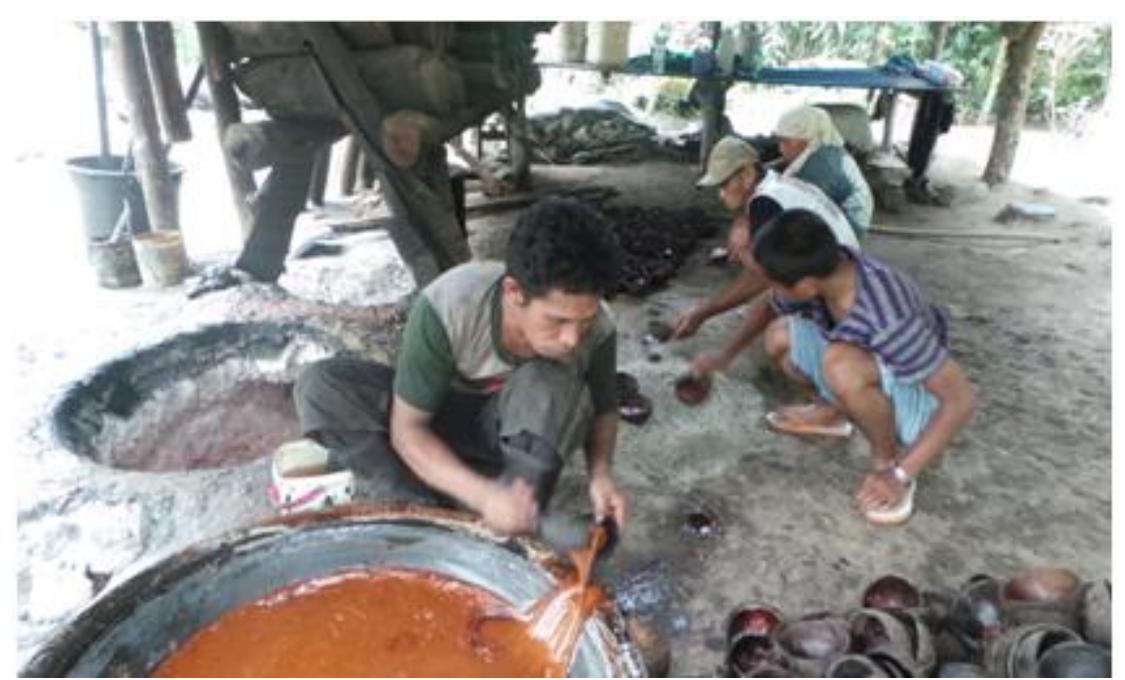

Figure 3. Thickening Process Palm Sugar and Ready to be Printed Source: Observations Documentation Researchers 2013/2014

\subsection{Impact of a Home-Based Business Industry}

The welfare of farmers' income to determine palm tappers used to make ends meet and for the improvement of the socio-economic welfare, can be seen in Table 1.

Table 1. Farmers Income Tapper According Sugar Land Area

\begin{tabular}{ccrcc}
\hline No & Farmers Acreage Tapper & Income / 2 Days & Farmers Tapper Aren & Percent (\%) \\
\hline 1 & $3-5$ hectare & 1.000 .000 & 30 & 30 \\
\hline 2 & 1.250 .000 & 750.000 & 40 & 40 \\
\hline 3 & $2-3$ hectare & 1.000 .000 & 30 & 30 \\
\hline & $1-2$ hectare & 650.000 & 100 & 100
\end{tabular}

Source: Primary Data on the Interview 2013/2014

In Table 1, the informant explained that 30 or $30 \%$ of farmers who have land tapper palm sugar 3 to 5 acres have an average income of IDR. 1.000.000,- to 1.250.000,- Infroman being 40 or $40 \%$ of farmers who have a bug 2 to 3 acres of land has an average income of IDR 750.000,- to 1,000,000,- and as many as 30 or $30 \%$ of farmers informant palm tappers that have 1-2 acres of land has a median income IDR. $450.000,-$ to $650,000,-$

With the income of farmers is excellent, so naturally if they can meet its needs will live food, clothing, shelter, health, education, and social, it can be understood that the success of the tapper farmers can improve the socio-economic welfare of farm families palm tapper [6]. To determine the socio-economic conditions of farming families welfare palm tappers will be illustrated with a level of subsistence including food, clothing, shelter, education, health, and social [7]. Next will be described on the food needs of family farmers palm tapper. Can be seen in Table 2 below.

Table 2. Levels Food Fulfillment Farmers Tapper

\begin{tabular}{clcc}
\hline No. & \multicolumn{1}{c}{ Levels Food Fulfillment } & Amount Craftsmen & $\%$ \\
\hline 1 & Eating 3 times a day and 4 healthy 5 perfect & 50 & 50 \\
\hline 2 & Nutritious meals 3 times a day & 30 & 30 \\
\hline 3 & Eating 3 times a day potluck & 20 & 20 \\
\hline & Total & 100 & 100 \\
\hline
\end{tabular}

Source: Primary Data on the Interview 2013/2014

Table 2 above shows that the level of food needs of family farmers palm tapper 50 informants majority or $50 \%$ of farmers palm tappers already meeting the food was good, they've been able to provide three meals a 
day with a nutritious meal, using either a side dish or animal protein such as fish, meat, eggs, and vegetable proteins like tempeh and vegetables, and it meets the needs of 4 healthy 5 perfect food that meets the needs of milk and fruits, so that these conditions indicates the level of welfare of the family are quite good. It is based on the work of the housing industry in the palm tappers farmers produce palm sugar. And as many as 30 or $30 \%$ of informants palm tappers farmers can meet the needs of three meals a day with a nutritious although not complete 4 healthy 5 perfect.

Being 20 or $20 \%$ of farmers informant tapper only needs 3 times a day with a potluck meal menu, but less attention to the needs of nutritious food and just fill a full stomach only. Thus, the condition of good food needs of farmers tapping palm indicates the level of welfare of the family is also good. Further elaborated about the degree of fulfillment of the needs of family farmers clothing palm tapper, can be seen in Table 3 as follows.

Table 3. Level Meeting the Needs Clothing

\begin{tabular}{clcc}
\hline No. & \multicolumn{1}{c}{ Conditions Farmers Tapper Sugar Board } & Amount Farmer & $\%$ \\
\hline 1 & Permanent home, clean, healthy, and beautiful & 50 & 50 \\
\hline 2 & Parmanen house, less beautiful but it is clean and healthy & 30 & 30 \\
\hline 3 & Houses Semi parmanen, less beautiful but quite clean and healthy & 20 & 20 \\
\hline & Total & 100 & 100 \\
\hline
\end{tabular}

Source: Primary Data on Observations and Interviews, 2013/2014

Table 3 illustrates that 50 informants or $50 \%$ palm tappers farmers already have good homes and parmanen and meet the elements of hygiene and health, such as windows, doors, air vents are quite a lot, as well as shower, washing, toilets were good. In addition it meets the elements of health, beauty with a garden in front of the house as well as a beautiful wall pengecatatan. It shows that the level of welfare of farming families have good palm tappers, due to building and maintaining the house with good, clean, healthy and beautiful requires a cost that much, so it needs to be supported by the economy are very adequate. Being as much as 30 or $30 \%$ of farmers informant palm tappers had homes parmanen, although no trace of beauty, but quite clean and healthy and also satisfy the elements of health. A total of 20 informants or 20 farmers have a home semi-palm tapper parmanen though not beautiful, but quite clean and healthy.

Thus it can be seen even though they only have a home semi parmanen but their attention to elements of hygiene and health, so this shows that the level of welfare of farming families palm tappers including both categories. To meet the needs of the board level can be seen in Table 4 as follows:

Tabel 4. Level of Compliance Needs Board

\begin{tabular}{clcc}
\hline No & Compliance Level Clothing & Amount Farmers Tapper & $\%$ \\
\hline 1 & Clothes are fulfilled as needed, grooming, health & 40 & 40 \\
\hline 2 & All types of clothing are met but neatness and health is still lacking & 50 & 50 \\
\hline 3 & Clothes on their backs and still fewer in number & 10 & 10 \\
\hline & Total & 100 & 100 \\
\hline
\end{tabular}

Source: Primary Data Observation, 2013/2014

Based on the data in Table 4 above, it can be explained that as much as 40 or $40 \%$ of informants palm tappers farmers can meet the needs of clothing well, they are able to dress in accordance with their needs, such as clothes for work, daily wear, clothes for prayer, clothes for worship, and sports clothing. They also pay attention to the element of neatness with ironing clothes, so it looks good enough. This shows that the level of welfare of farmers palm tappers are excellent and include a prominent family in the village environment.

Being as much as 50 or $50 \%$ of informants palm tappers farmers can meet the needs of clothing but do not meet the neatness and health, their clothes are still limited and does not vary, such as daily wear for work and worship. Meanwhile, 10 informer or $10 \%$ of farmers still dressed palm tappers sober and still few in number. Further proposed education level of family members / children of farmers palm tappers can be seen in Table 5 as follows:

Table 5. Member Education Family Farmers Tapper Aren

\begin{tabular}{clcc}
\hline No & $\begin{array}{c}\text { The Education Level of Family Members of } \\
\text { Farmers Tapping Palm }\end{array}$ & Number of Farmers/Tapper & $\%$ \\
\hline 1 & Bachelor of S1, D3, D2 & 60 & 60 \\
\hline 2 & High School & 20 & 20 \\
\hline 3 & Secondary Schools & 15 & 25 \\
\hline 4 & Elementary School & 5 & 5 \\
\hline & Total & 100 & 100 \\
\hline
\end{tabular}

Source: Primary Data on the Interview, 2013/2014 
Based on the data in Table 5 illustrates that the education level of farmers tapping the palm family members has been very good with 60 informants or $60 \%$ palm tappers farmers have been able to send their children to college, and as many as 20 or $20 \%$ of informants palm tappers farmers have been able to send their children to High School, informants were 15 or $15 \%$ of farmers have tapper arena sending their child to Secondary Schools, and as many as five informants farmers or 5\% palm tappers who send their children only up to Elementary School. In this case the palm tappers farmers admit that they are actually able to send their child to a higher level, but his own son, who had no interest for further study.

Therefore, based on interviews, observation and recognition of farmers palm tapper, it can be concluded that the level of welfare of farming families palm tappers are good enough, because in order to achieve a higher education, the cost factor is very important, as well as motivation, and guidance of good parents, so that the success of a family member can be reached. To find factors that do address the health palm farmers can be seen in Table 6 .

Table 6. Family Member Health Factors Farmers Tapper

\begin{tabular}{clcc}
\hline No & \multicolumn{1}{c}{ Overcoming Health Factor } & The Number of Farmers Palm Tapper & $\%$ \\
\hline 1 & $\begin{array}{l}\text { Health Center, General Hospital, } \\
\text { Doctors, Midwives }\end{array}$ & 70 & 70 \\
\hline 2 & $\begin{array}{l}\text { Traditional Medicine, Herbalists, } \\
\text { Paranormal }\end{array}$ & 20 & 20 \\
\hline 3 & Treated himself to buy in the shop & 10 & 10 \\
\hline & Total & 100 & 100 \\
\hline
\end{tabular}

Source: Primary Data on the Interview 2013/2014

Based on data from Table 6 can be explained that: 70 informants or $70 \%$ palm tappers farmers admit that when members kelurga experience pain or other health problems, they will do to the health center or treatment of General Hospital, the doctor or midwife. Thus, this shows that family farmers already concerned about sugar tapper health by addressing disease. These conditions indicate the level of welfare of farm families palm tappers good enough.

Being 20 or $20 \%$ of farmers informant palm tappers to admit that usually when a health problem is not too severe, they are quite traditional concoction of drugs alone or to a traditional healer, a psychic who has the expertise to care, because the traditional medicine concoction itself does not require substantial costs. This is due to the ability of families with health problems is low, and the mindset of those who are still traditional, these conditions shows that the welfare level is still low.

A total of 10 informants or $10 \%$ palm tappers farmers admit that if a family member illness, usually treated themselves to traditional ingredients, or buy the drug store / pharmacy. Thus, health factors and efforts to overcome health problems indicates the level of welfare of farming families palm tapper.

Table 7. Social Harmony Public Relations

\begin{tabular}{clcc}
\hline No. & \multicolumn{1}{c}{ Harmony Social Relations } & Farmers Tapper Aren & $\%$ \\
\hline 1 & $\begin{array}{l}\text { The relationship between the family and the } \\
\text { society harmoniously intertwined }\end{array}$ & 70 & 70 \\
\hline 2 & $\begin{array}{l}\text { The relationship between members of the } \\
\text { regular established }\end{array}$ & 20 & 20 \\
\hline 3 & $\begin{array}{l}\text { Intertwined relationships between family } \\
\text { members are less harmonious }\end{array}$ & 10 & 10 \\
\hline
\end{tabular}

Source: Primary Data on Observations and Interviews 2013/2014

Based on observations and interviews with farmers in three villages tapping palm South Halmahera district can be seen that the majority of the 70 informants or $70 \%$ of farmers tapping palm able to acknowledge that relationships between family members as well as with other family members, remain intertwined harmoniously and smoothly, social relations activity good in the family is a respectful relationship between the younger to the older, language, manners, good manners, helping those in need, community service implemented babari village (mutual help) and contributed to the carrying out of a lavatory or thanksgiving.

Meanwhile, 20 informer or $20 \%$ of farmers tapping the public arena recognize the relationship between ordinary intertwined, each taking care of their own work, and 10 informants farmers palm tappers or $10 \%$ recognized the relationship between family members is less harmoniously intertwined due to upbringing parents to children less, and also the influence of modernization is incompatible with the culture of the local indigenous people, such as drunkenness, gambling, promiscuity which can damage the morale of the younger generation, so they wills arbitrarily without care for the elderly and the surrounding communities. 
Thus the farmer family harmony with the surrounding community palm tappers village is also one indicator of good social relationships and a good level of social welfare. Based on the discussed shows that farmers palm tappers in southern Halmahera district can improve the welfare of the family be able to meet the necessities of life such as food, clothing, shelter, education, health, and social well.

\section{Conclusion}

This study concluded that the activities of the housing industry in the palm tapper farmers South Halmahera Regency will contribute to improving the welfare of farm families palm tappers such as the need for food, clothing, shelter, education, health, and a good social life. This can be realized because the income of farmers tapping palm adequate enough to meet the needs of family life. So farmers tapper can also open employment opportunities, and to develop a home-based business industry by utilizing forest resources on their land, so that the business of making palm sugar can be exported to neighboring areas and can improve the socioeconomic welfare of farmers palm tappers in South Halmahera.

\section{References}

[1]. Soeseno. S,. Palm Cultivation, Penebar Swadaya, Jakarta, 1995

[2]. Mahmud Z. D. Allorerung and Amrizol,. The prospect of a Plant coconut, areca palm, Lontar and Gewang to produce sugar,. Bulletin Balitka No. 14:90 - 105, 1991

[3]. Soeseno, S,. Sugar Farming. P.T. Diffuser Organization, Jakarta. 2000

[4]. Rumokoy, M. M. M.. Benefits of Sugar Crop (Arenga pinnata Merr) Bulletin Baluka, 2000

[5]. Endang R. Sedyaningsih, Vivi Setiawaty, Lutfah Rif'ati, Syahrial Harun, Bambang Heriyanto, Krisna Nur AP, Hana Apsari P, Elvieda Sariwati, Chita Saptiawati, Erna Tresnaningsih, Characteristics of human H5N1 cases in Indonesia, July 2005 - May 2006. Health Research Bulletin (2006), 34(4): 137146.

[6]. Bank Indonesia,. The Pattern of Business Financing Palm Sugar, Jakarta, 2008

[7]. The National Population and Family Planning. Welfare Index, Jakarta, 2000 